\title{
Rancang Bangun Sistem Informasi Geografis Pelanggan Unit Jasa Pengelolaan Sampah pada BUMDesa Catu Krewo Sedana
}

\author{
Komang Kurniawan Widiartha*¹,I Kadek Budi Sandika ${ }^{2}$, Desak Putu Diah Kumala Dewi ${ }^{3}$ \\ 1,2,3 Teknik Informatika,STMIK STIKOM Indonesia; Denpasar, Indonesia \\ e-mail: *11 komang.kurniawan@stiki-indonesia.ac.id, ${ }^{2}$ ikbsandika@stiki-indonesia.ac.id, \\ 3desakdiah@stiki-indonesia.ac.id
}

\begin{abstract}
Abstrak
Badan Usaha Milik Desa (BUMDesa) Catu Kwero Sedana merupakan BUMDesa yang terdapat di desa Pecatu, Kecamatan Kuta Selatan, Kabupaten Badung-Bali. Mekanisme penanganan sampah yang dilakukan unit jasa pengelolaan sampah pada BUMDesa Catu Kwero Sedana ini adalah pengambilan sampah ke rumah-rumah penduduk atau tempat usaha yang ada di desa Pecatu. BUMDesa ini menitikberatkan pada kualitas layanan yang diberikan kepada pelanggannya. Sampai saat ini masih ada keluhan para pelanggan, terutama pelanggan baru dan calon pelanggan terkait dengan awal mulainya pelayanan dan/atau pendaftaran sebagai pelangan baru. Permasalahan yang sering terjadi adalah kesulitan mencari lokasi pengambilan sampah di tempat pelanggan. Jika pelanggan mendaftarkan diri melalui kolektor iuran yang sedang memungut tagihan pelanggan, karyawan yang bertugas mengangkut sampah yang kadang terkendala menemukan lokasi pelanggan. Selain itu, terkait besarnya tarif yang akan dikenakan kepada pelanggan. Karyawan pengangkut sampah yang tidak mengetahui besarnya tarif iuran pelanggan akan kesulitan memberikan kisaran tarif yang akan dikenakan kepada pelanggan sesuai dengan aturan yang tercantum pada peraturan desa Pecatu. Untuk mengatasi permasalahan tersebut, diperlukan adanya sebuah sistem yang dapat memberikan informasi kepada karyawan pengangkut sampah mengenai posisi/lokasi pengambilan sampah masing-masing pelanggan, besarnya tarif sesuai dengan peraturan yang berlaku, dan rekapitulasi pembayaran iuran pelanggan. Sistem informasi ini dapat dikembangkan berbasis website dengan model sistem informasi geografis (SIG) dengan memanfaatkan fitur Application Programming Interface (API) maps yang dimiliki oleh Google. Penerapan SIG pada pengelolaan sampah telah banyak diteliti dan menunjukkan hasil yang positif.
\end{abstract}

Kata kunci-Sistem Informasi, Sistem Informasi Geograsi, Google Map, Sampah, Bumdesa

\begin{abstract}
Badan Usaha Milik Desa (BUMDesa) Catu Kwero Sedana is BUMDesa located in Pecatu village, South Kuta District, Badung-Bali Regency. The waste handling mechanism carried out by the waste management service unit at the BUMDesa Catu Kwero Sedana is the collection of garbage to residents' houses or businesses in the village of Pecatu. BUMDesa focuses on the quality of services provided to its customers. Until now there are still complaints from customers, especially new customers and prospective customers, related to the start of service and / or registration as new customers. The problem that often occurs is the difficulty of finding the location of garbage collection at the customer's site. If the customer registers himself through a contribution collector who is collecting customer bills, the employee in charge of transporting waste is sometimes constrained to find the customer's location. In addition, related to the amount of tariffs that will be charged to customers. Employees of garbage transport who do not know the size of the contribution rates of customers will find it difficult to provide the range of tariffs that will be charged to customers according to the rules
\end{abstract}

Received May $1^{\text {st }}, 2012 ;$ Revised May 25 ${ }^{\text {th }}$, 2020; Accepted June 30 ${ }^{\text {th }}, 2020$ 
stated in the regulations of Pecatu village. To overcome these problems, it is necessary to have a system that can provide information to employees of garbage transport regarding the position / location of garbage collection of each customer, the amount of tariff in accordance with applicable regulations, and recapitulation of payment of customer contributions. This information system can be developed based on websites with a geographic information system (GIS) model by utilizing the Application Programming Interface (API) maps owned by Google. The application of GIS to waste management has been extensively investigated and shows positive results.

Keywords - information system, geographic information system, google map, garbage, bumdesa

\section{PENDAHULUAN}

$\mathrm{B}$ adan Usaha Milik Desa (BUMDesa) Catu Kwero Sedana merupakan BUMDesa yang terdapat di desa Pecatu, Kecamatan Kuta Selatan, Kabupaten Badung-Bali. BUMDesa ini didirikan berdasarkan Perdes Pecatu Nomor 1 Tahun 2014, tanggal 30 September 2014. BUMDesa ini mulai beroperasi mulai pertengahan tahun 2017 dengan satu unit usaha, yaitu unit jasa pengelolaan sampah. Sampai bulan April 2019, jumlah karyawan sebagai tenaga angkut sampah keliling sebanyak lima belas (15) orang tenaga pilah di tempat pengelolaan sampah terpadu sebanyak empat belas (14) orang, dan satu (1) orang kolektor iuran sampah, dengan daerah pelayanan hampir seluruh wilayah desa Pecatu. Untuk melayani pengangkutan sampah, unit usaha ini menggunakan tiga jenis kendaraan, yaitu sebuah kendaraan roda tiga yang memiliki bak, dua buah mobil sejenis pick up, dan sebuah truk.

Adapun mekanisme penanganan sampah yang dilakukan unit jasa pengelolaan sampah pada BUMDesa Catu Kwero Sedana ini adalah pengambilan sampah ke rumah-rumah penduduk atau tempat usaha yang ada di desa Pecatu. Sampah yang sudah dinaikkan kedalam kendaraan pengangkut kemudian dibawa ke tempat pengelolaan sampah terpadu (TPST) untuk dipilah dan diproses lebih lanjut. Setiap pelanggan yang dilayani dikenakan jasa pengangkutan sampah yang dibayar setiap satu bulan sekali dengan tarif mengacu pada peraturan desa Pecatu.

Sebagai unit usaha jasa, maka BUMDesa ini menitikberatkan pada kualitas layanan yang diberikan kepada pelanggannya. Sampai saat ini masih ada keluhan para pelanggan, terutama pelanggan baru dan calon pelanggan terkait dengan awal mulainya pelayanan dan/atau pendaftaran sebagai pelangan baru. Prosedur yang diberlakukan sampai saat ini adalah calon pelanggan diwajibkan mengisi formulir pendaftaran sebagai calon pelanggan sebelum dapat dilayani untuk diangkut sampahnya. Formulir tersebut bisa didapatkan dari caretaker direktur BUMDesa, kolektor iuran, petugas angkut sampah, atau mendaftar di kantor BUMDesa.

Permasalahan yang sering terjadi adalah kesulitan mencari lokasi pengambilan sampah di tempat pelanggan. Jika pelanggan mendaftarkan diri melalui kolektor iuran yang sedang memungut tagihan pelanggan, karyawan yang bertugas mengangkut sampah yang kadang terkendala menemukan lokasi pelanggan. Namun, jika pelanggan mendaftar kepada karyawan pengangkut sampah, maka kolektor iuran yang kadang menghadapi kendala terkait pengambilan iuran jasa pengangkutan sampah.

Permasalahan lainnya adalah terkait besarnya tarif yang akan dikenakan kepada pelanggan. Karyawan pengangkut sampah yang tidak mengetahui besarnya tarif iuran pelanggan akan kesulitan memberikan kisaran tarif yang akan dikenakan kepada pelanggan sesuai dengan aturan yang tercantum pada peraturan desa Pecatu. Kolektor iuran sampah biasanya melakukan dua kali pencatatan pembayaran yang dilakukan oleh pelanggan, yaitu saat bertemu pelanggan berupa catatan manual, dan setelah sampai di kantor di input ke komputer untuk dibuatkan softcopynya. Selain itu, untuk mengetahui jumlah pelanggan seluruhnya, jumlah pelanggan yang telah membayar dan belum membayar hanya bisa diketahui ketika membuka berkas yang ada di komputer.

JSIKTI Vol. 2, No. 3, June: 11-20 
Untuk mengatasi permasalahan tersebut, diperlukan adanya sebuah sistem yang dapat memberikan informasi kepada karyawan pengangkut sampah mengenai posisi/lokasi pengambilan sampah masing-masing pelanggan, besarnya tarif sesuai dengan peraturan yang berlaku, dan rekapitulasi pembayaran iuran pelanggan. Sistem informasi ini dapat dikembangkan berbasis website dengan model sistem informasi geografis (SIG) dengan memanfaatkan fitur Application Programming Interface (API) maps yang dimiliki oleh Google. Penerapan SIG pada pengelolaan sampah telah banyak diteliti dan menunjukkan hasil yang positif. Pemanfaatan model berbasis SIG meningkatkan sistem pengangkutan sampah, baik dari sisi waktu maupun jarak, yang pada akhirnya dapat menekan biaya operasional [1][2][3].

\section{METODE PENELITIAN}

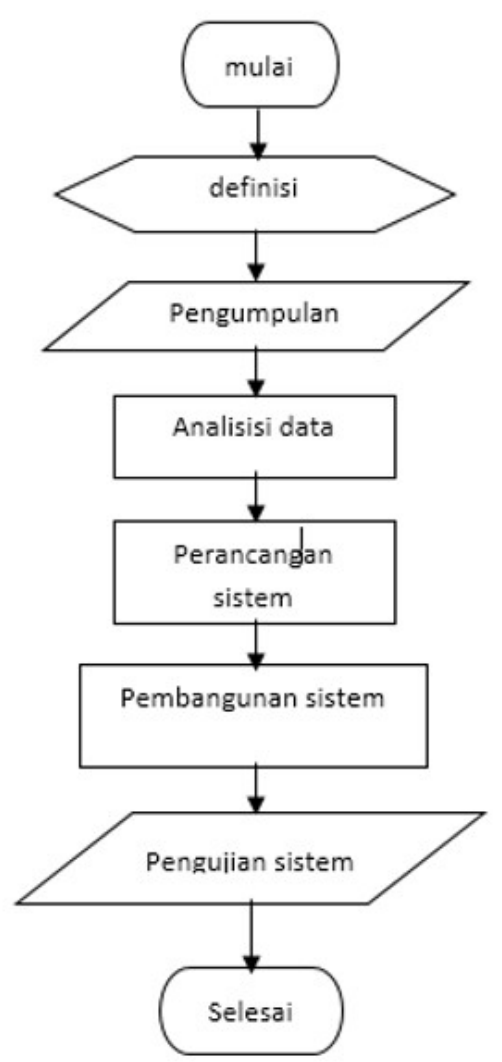

Gambar 1. Alur penelitian

\subsection{Alur Penelitian}

Penelitian ini diselesaikan dengan melalui tahapantahapan sebagai berikut.

Tahapan pertama dari penelitian ini adalah melakukan pendefinisian masalah yang ingin diselesaikan. Setelah mendefinisikan masalah yang ingin dipecahkan langkah berikutnya adalah melakukan pengumpulan data untuk mendukung penyelesaian permasalahan yang dihadapi. Setelah data yang diperlukan terkumpul, data dianalisis sebagai dasar dalam merancang sistem informasi geografis unit jasa pengelolaan sampah. Setelah analisis data terpenuhi, mulailah dengan merancang dilanjutkan dengan membangun sistem informasi. Sistem informasi yang dibangun hendaknya sudah dapat diimplementasikan untuk menjawab permasalahan yang ada. Jika luaran telah sesuai dengan harapan maka tahapan penelitian telah selesai.

\subsection{Pengumpulan Data}

Pengumpulan data dilakukan dengan studi literatur dan observasi pada objek penelitian.

1. Studi Literatur/Kepustakaan

Melakukan studi literatur di beberapa penelitian, jurnal yang ada dan buku sebagai referensi untuk mendapatkan acuan dalam melakukan perancangan dan pembangunan sistem informasi geografis unit jasa pengelolaan sampah.

2. Observasi

Kegiatan pengumpulan data dilakukan dengan mengamati proses manajemen pelanggan jasa pengelolaan sampah serta mengkaji proses kegiatan dalam mencari alamat pelanggan untuk diambil sampahnya.

\section{Wawancara}

Pada pengumpulan wawancara, peneliti melakukan wawarncara kepada bapak Budi Sandika, selaku salah satu pengelola Badan Usaha Milik Desa terkait jasa pengelolaan sampah. 


\subsection{Gambaran Umum Sistem}

Sistem yang dibangun adalah sebuah sistem informasi pengelolaan pelanggan unit jasa pengolahan sampah. Sistem yang dibangun dengan bahasa pemrograman PHP serta didukung dengan MySQL sebagai databasenya, dapat mengelola pelanggan pengelohan sampah dengan memanfaatkan Google Map untuk mempermudah dalam pencarian lokasi pelanggan. Dengan sistem ini, staff lapangan dengan mudah mencari lokasi rumah pelanggan dan mendata data terkait pengelolaan sampah. Disamping itu, sistem yang dibangun dapat mengelola sisi pembayaran. Nantinya pengelola dapat dengan mudah melakukan pencatatan terkait pembayaran yang dilakukan oleh pelanggan, dimana pelanggan tanpa harus datang ke kantor, melainkan akan dipungut langsung oleh staff lapangan dengan mencatat transaksi pembayaran melalui sistem informasi web.

\subsection{Context Diagram}

Dalam perancangan sistem, digunakan data flow diagram yang dimulai dengan penggambaran perancangan context diagram. Diagram konteks adalah diagram yang terdiri dari suatu proses dan menggambarkan ruang lingkup suatu sistem. Diagram konteks merupakan level tertinggi dari DFD yang menggambarkan seluruh input ke dalam sistem atau output dari sistem yang memberi gambaran tentang keseluruhan sistem [4]. Gambar 2 menggambarkan context diagram sistem informasi geografis pengelolaan pelanggan unit jasa pengolahan sampah.

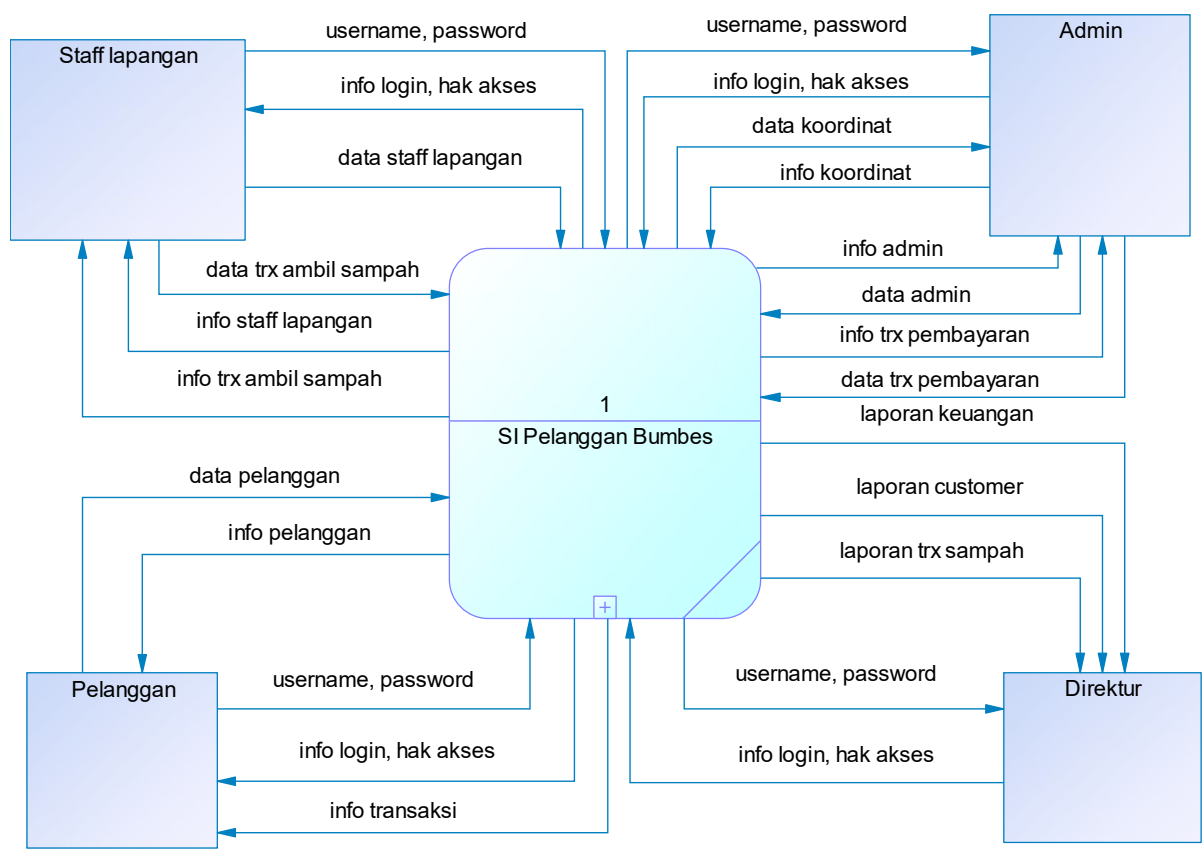

Gambar 2. Context Diagram

\subsection{Data Flow Diagram (Diagram 0)}

Penggambaran secara detail dari aliran data pada sistem informasi disajikan dalam Data

Flow Diagram Level 1 atau Diagram Nol. Diagram nol/Zero adalah diagram yang menggambarkan proses dari data flow diagram. Diagram nol memberikan pandangan secara menyeluruh mengenai sistem yang ditangani, menunjukkan tentang fungsi-fungsi utama atau proses yang ada, aliran data, dan eksternal entity [4]. Gambar 3.2 menggambarkan DFD Level 1 atau Diagram Nol sistem informasi geografis pengelolaan pelanggan unit jasa pengolahan sampah. 


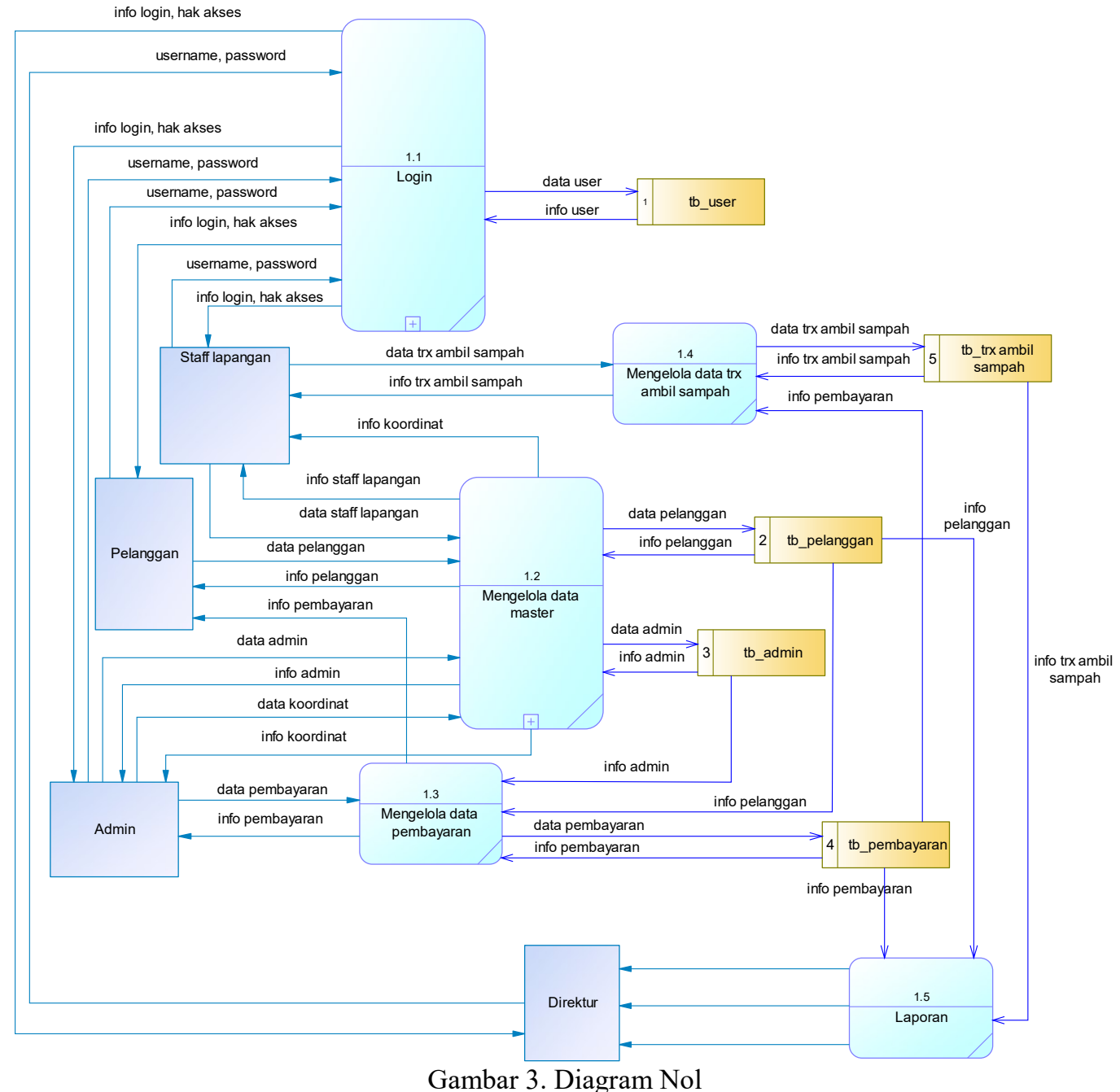

\subsection{Conceptual Data Model}

Conceptual Data Model (CDM) adalah sebuah representasi seluruh muatan informasi yang dikandung oleh basis data. Pada CDM, keberadaan tidak memperhitungkan kekurangan perangkat keras maupun perangkat lunak dalam pembangunan basis data. Dalam penelitian ini digambarkan Conceptual Data Model pada Gambar 4 [5].

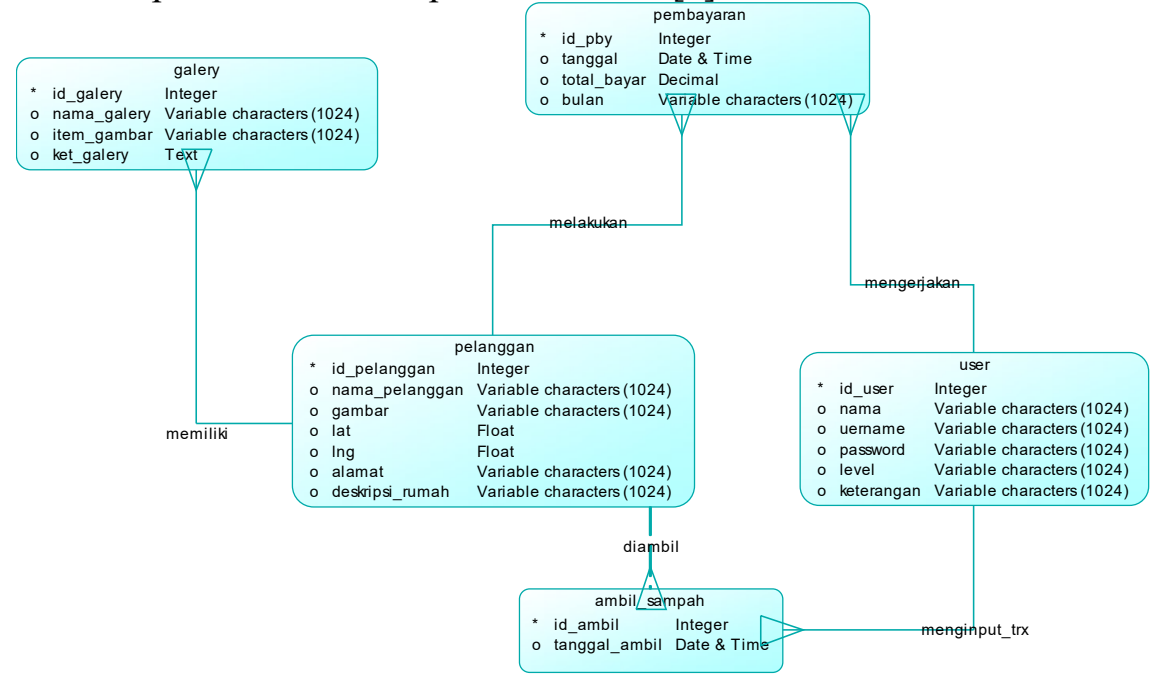

Gambar 4. Conceptual Data Model 


\subsection{Physical Data Model}

Physical Data Model (PDM) menjelaskan bagaimana data disimpan di komputer dengan menyajikan informasi seperti record formats, record orderings dan acces path. PDM dibuat dengan melakukan generate pada CDM yang sudah dibuat. PDM pada penelitian ini digambarkan pada Gambar 5 [6].

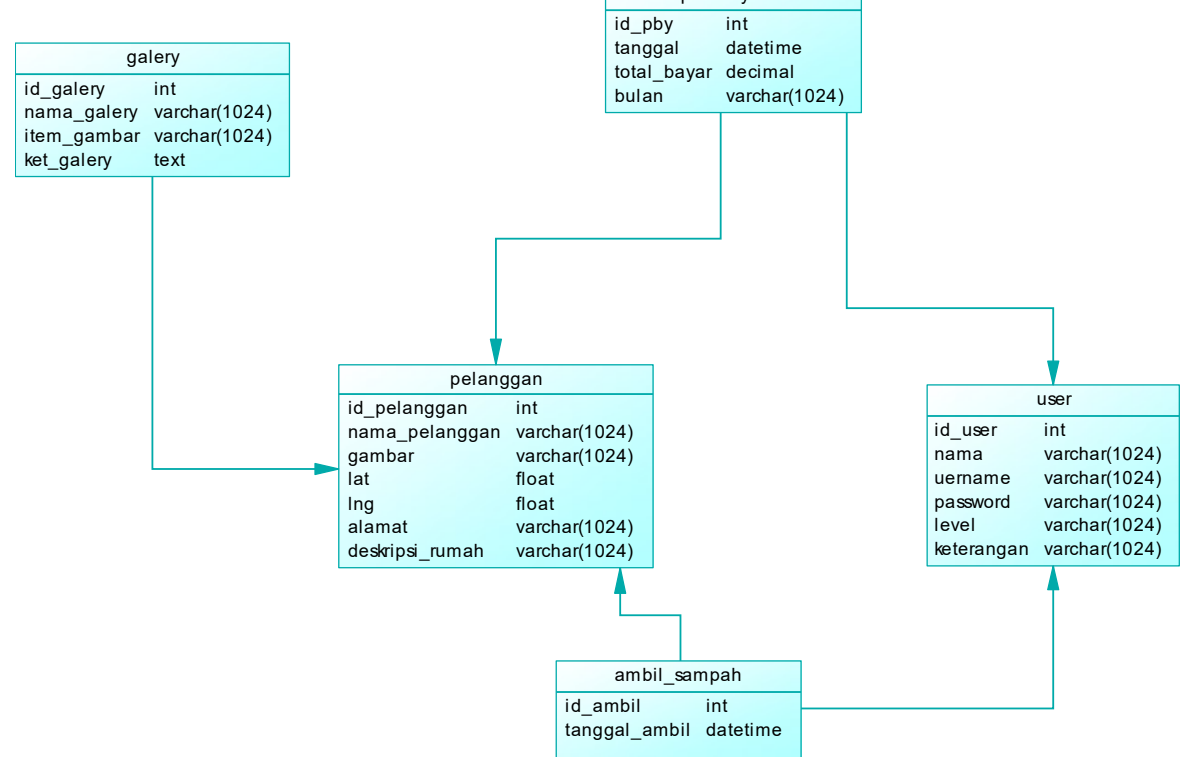

Gambar 5. Physical Data Model

\subsection{Pengujian Sistem}

Dalam penelitian ini, penulis menggunakan Black box testing dalam pengujiannya. Black Box testing adalah pengujian yang dilakukan hanya mengamati hasil eksekusi melalui data uji dan memeriksa fungsional dari perangkat lunak. Jadi dianalogikan seperti kita melihat suatu koatak hitam, kit hanya bisa melihat penampilan luarnya saja, tanpa tau ada apa dibalik bungkus hitam nya. Sama seperti pengujian black box, mengevaluasi hanya dari tampilan luarnya (interface nya), fungsionalitasnya.tanpa mengetahui apa sesungguhnya yang terjadi dalam proses detilnya (hanya mengetahui input dan output) [7].

Metode uji yang akan diterapkan adalah pada semua tingkat pengujian perangkat lunak: unit, integrasi, fungsional, sistem dan penerimaan.

Pada pengujian pada Black Box penulis menguji :

a. Fungsi-fungsi yang tidak benar atau hilang

b. Kesalahan interface

c. Kesalahan dalam struktur data atau akses database eksternal

d. Kesalahan kinerja

e. Inisialisasi dan kesalahan terminasi

\section{HASIL DAN PEMBAHASAN}

\subsection{Form Login Sistem}

Form login ditujukan untuk mengakses fitur dalam pengelolaan data pelanggan. Dengan menginputkan username dan password untuk user yang sudah terdaftar dalam database. Dalam sistem ini yang dapat melakukan login ke sistem terbatas pada karyawan Bumdes Catu Krewo Sedana serta sopir yang bertugas dalam mengangkut sampah ke rumah pelanggan. Form login sistem digambarkan pada Gambar 6. 


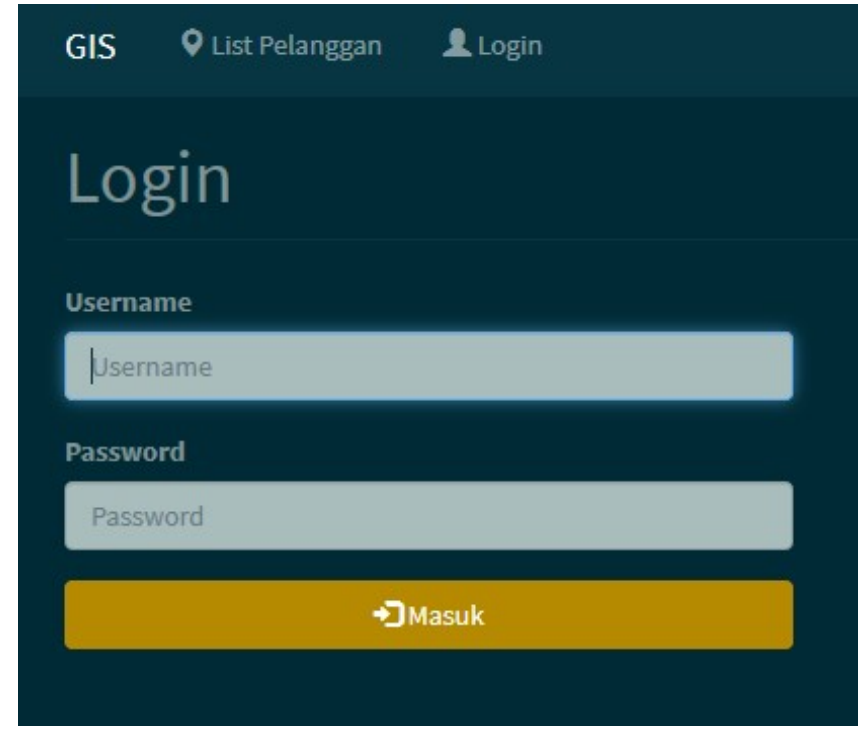

Gambar 6. Form Login

\subsection{Dashboard}

Form dashboard ditampilan setelah berhasil melakukan proses login ke sistem. Pada form ini ditampilkan secara menyeluruh data pelanggan dalam gambar pemetaan map. Dengan dashboar ini, mempermudah melihat cluster pelanggan yang tersebar di beberapa area dalam map. Icon memiliki aksi untuk menampilkan detail pelanggan jika diklik dan langsung menampilkan data detail pelanggan yang digambarkan pada Gambar 7.

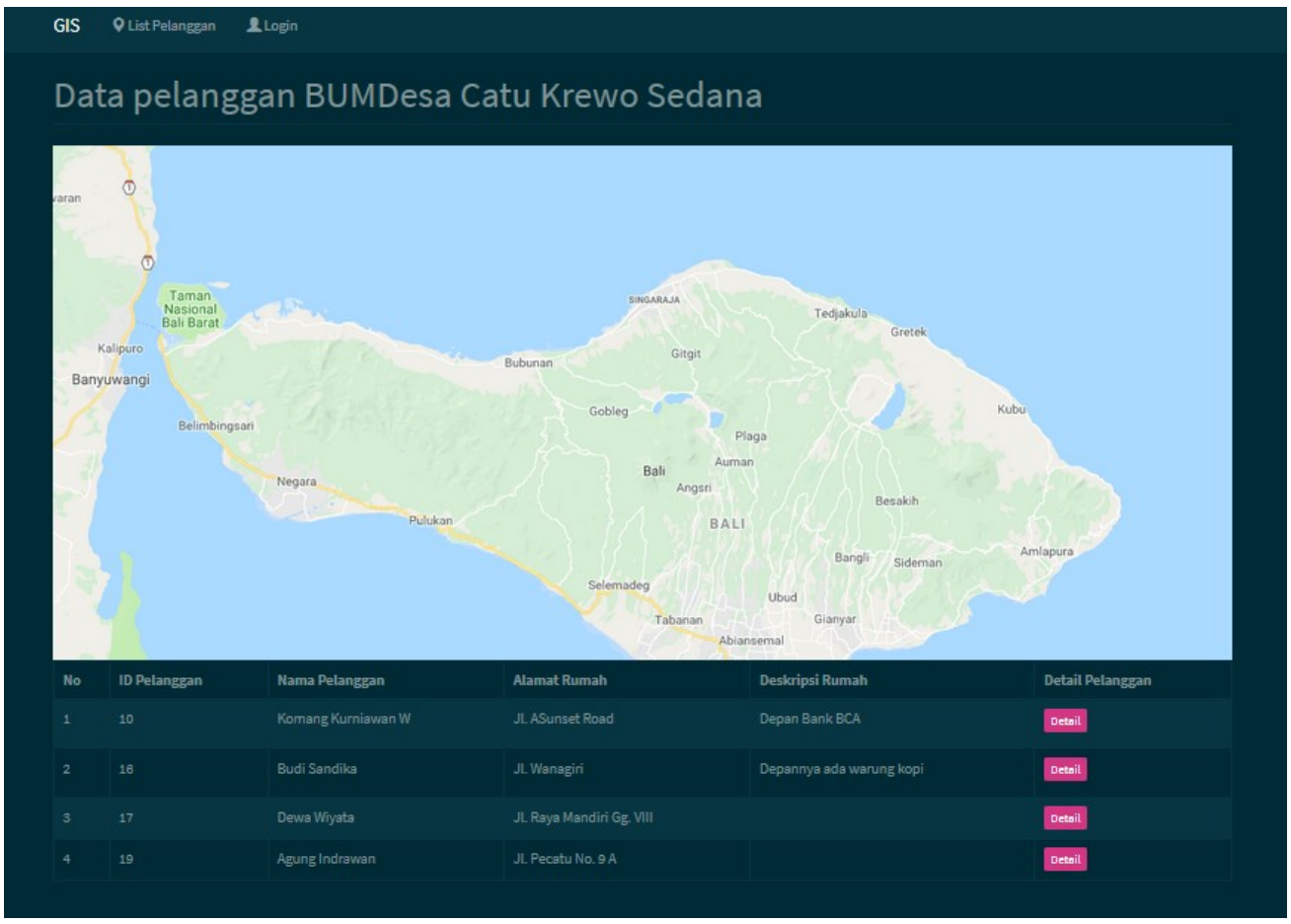

Gambar 7. Dashboard Sistem 


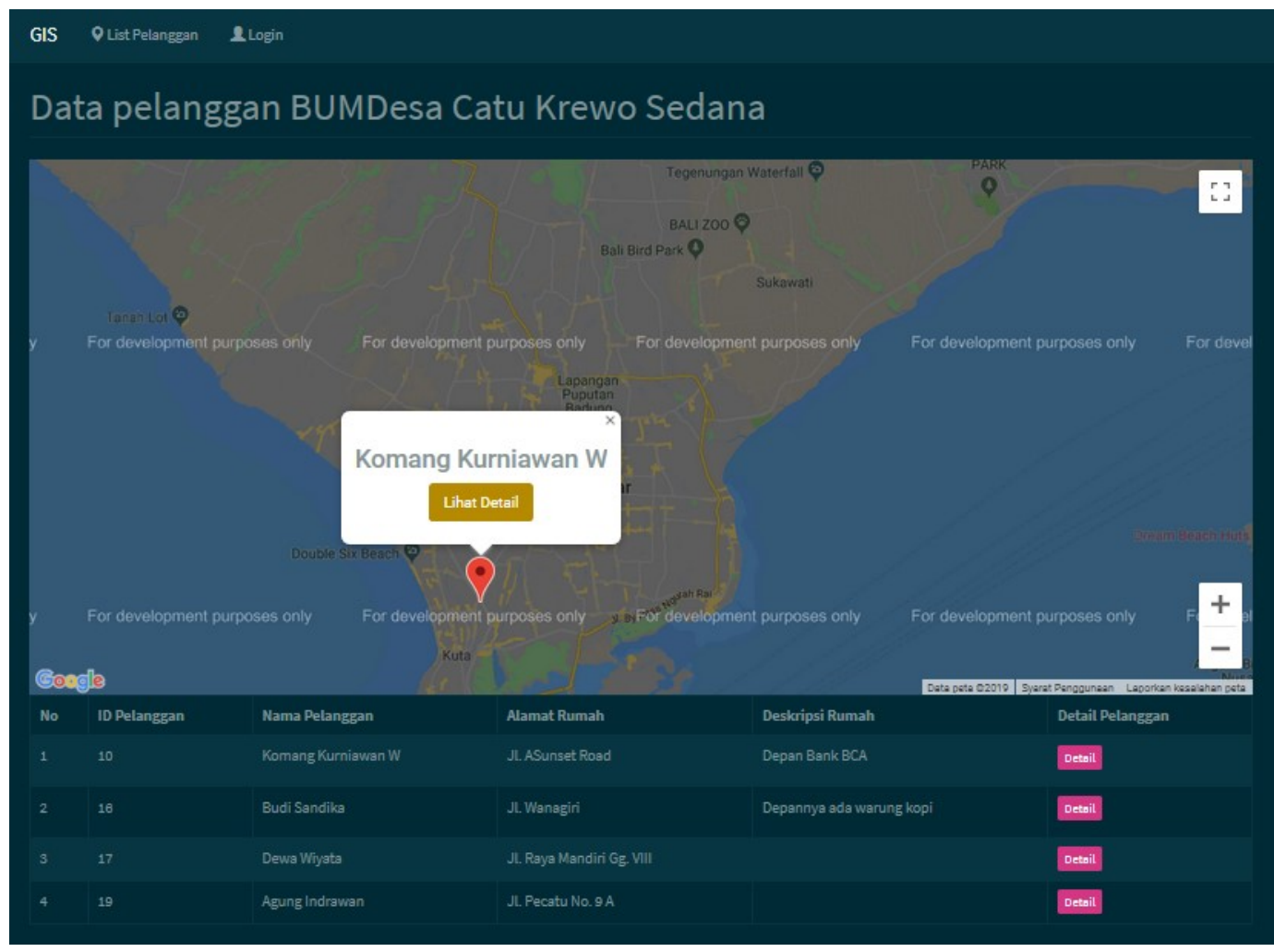

Gambar 8. Aksi pada Form Dashboard

\subsection{Form Kelola Data Pelanggan}

Form kelola pelanggan digunakan untuk mengelola data pelanggan. Pada form ini disediakan buttom untuk menambah serta mengedit pelanggan. Masing-masing buttom menampilkan aksi sesuai buttom yang dipilih. Form kelola data pelanggan ditampilkan pada Gambar 9.

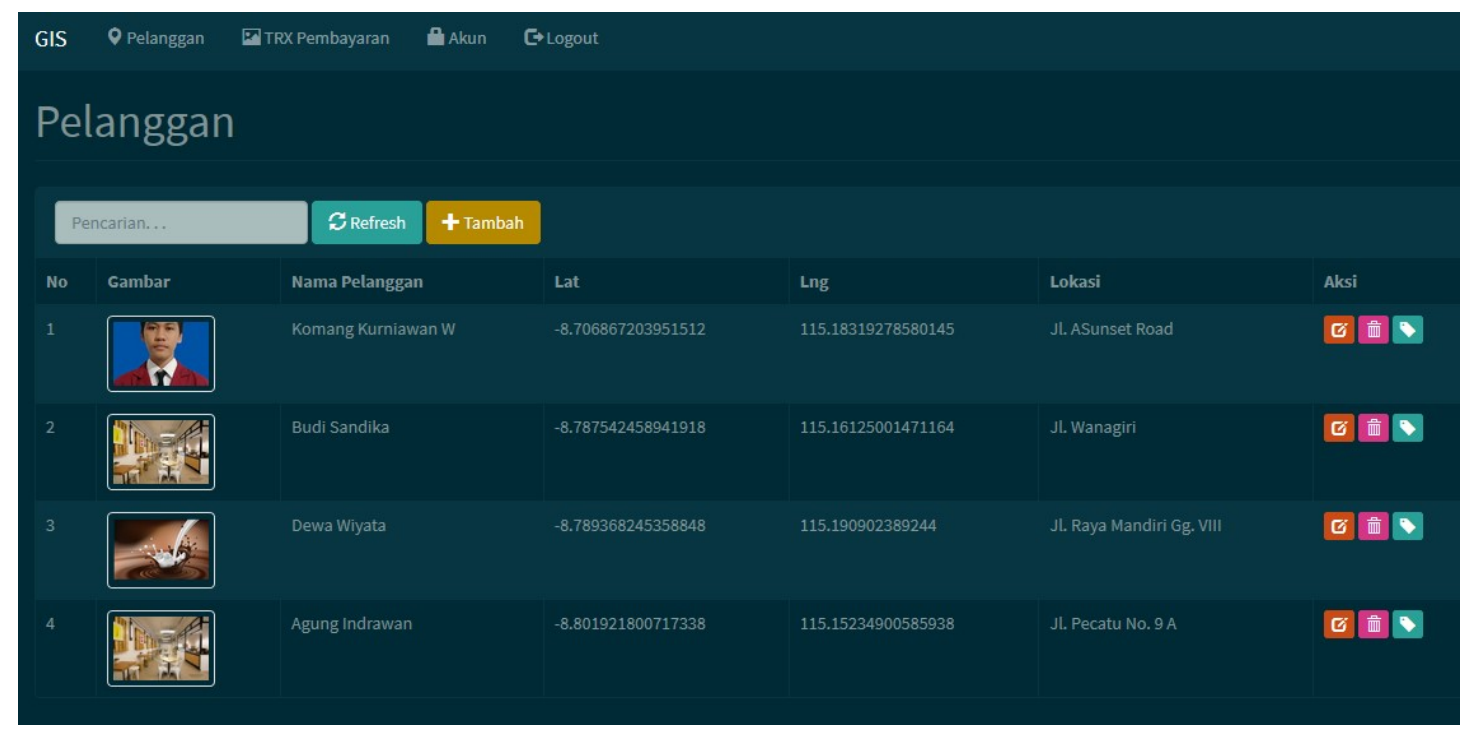

Gambar 9. Form kelola data pelanggan

\subsection{Form Detail Data Pelanggan}

Halaman form detail data pelanggan, menampilkan secara detail dari pelanggan yang dipilih. Pada halaman ini menampilkan detail pelanggan dari lokasi secara individu pada sebuah

JSIKTI Vol. 2, No. 3, June: 11-20 
map, menampilkan histori transaksi pembayaran untuk pelanggan yang dipilih. Dalam form ini pula, map dapat menampilkan lokasi terkini staff lapangan dan disediakan buttom untuk mencari jalur terpendek untuk mencapai lokasi pelanggan. Gambar 10 menggambarkan form detail data pelanggan.

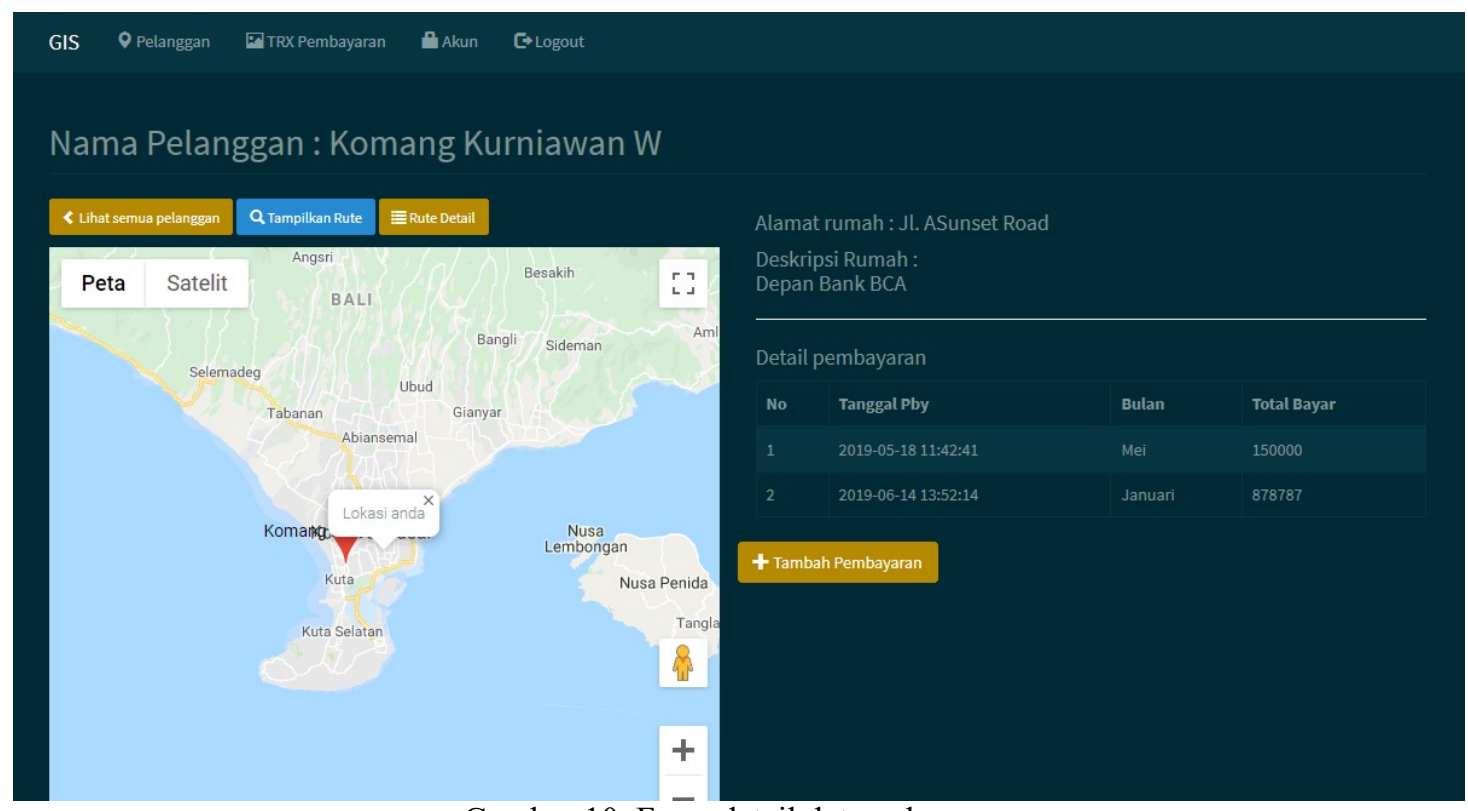

\subsection{Form Tambah Transaksi Pembayaran}

Gambar 10 yang menampilkan form detail data pelanggan, user dapat melakukan pengelolaan data pembayaran pelanggan yang dipilih. Dengan mengklik buttom Tambah Transaksi, user akan disajikan form untuk mengelola tambah transaksi pembayaran yang digambarkan pada Gambar 11.

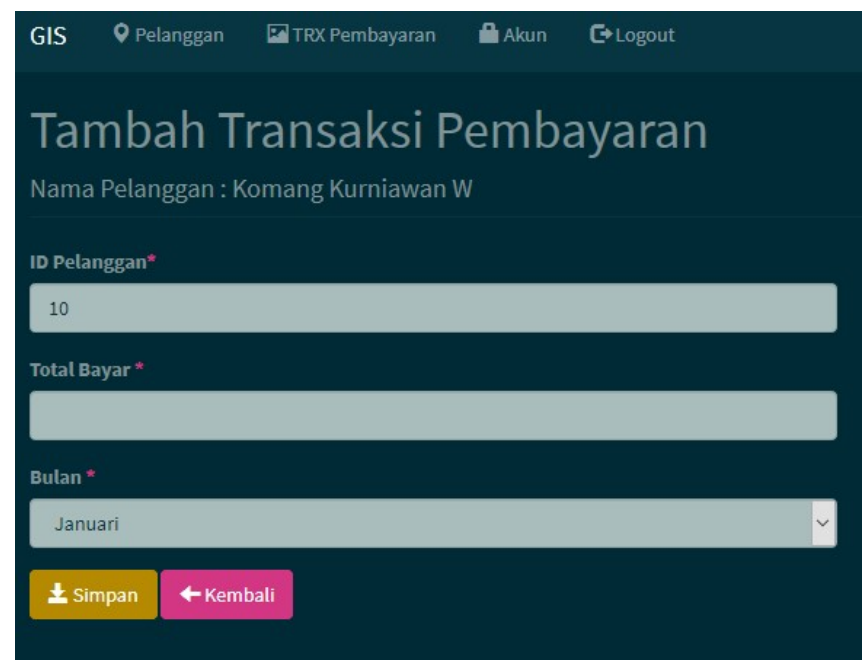

\subsection{Pengujian}

Gambar 11. Form tambah data pembayaran

Berdasarkan pengujian yang telah dilakukan oleh peneliti melalui pengujian alfa dengan metode Blackbox Testing, dari total item pengujian sebanyak 18, diperoleh hasil pengujian dengan prosentase $94.44 \%$ untuk nilai S (Sesuai) dan 5.56\% untuk nilai TS (Tidak Sesuai). Nilai S (Sesuai) menyatakan bahwa pengujian yang dilakukan hasilnya sesuai dengan standar pengujian. Sedangkan pada hasil TS (Tidak Sesuai) ketika dilakukan pengujian terdapat beberapa hasil output yang masih belum sesuai dengan standar pengujian. 


\section{KESIMPULAN}

Dalam penelitian ini, penulis menggunakan Black box testing dalam pengujiannya. Black Box testing adalah pengujian yang dilakukan hanya mengamati hasil eksekusi melalui data uji dan memeriksa fungsional dari perangkat lunak. Jadi dianalogikan seperti kita melihat suatu koatak hitam, kita hanya bisa melihat penampilan luarnya saja, tanpa tau ada apa dibalik bungkus hitam nya. Pada pengujian black box, evaluasi hanya dari tampilan luarnya (interface), fungsionalitasnya tanpa mengetahui apa sesungguhnya yang terjadi dalam proses detilnya (hanya mengetahui input dan output) [7].

Metode uji yang diterapkan adalah pada semua tingkat pengujian perangkat lunak: unit, integrasi, fungsional, sistem dan penerimaan.

Pada pengujian sistem, peneliti menguji :

1. Fungsi-fungsi yang tidak benar atau hilang

2. Kesalahan interface

3. Kesalahan dalam struktur data atau akses database eksternal

4. Kesalahan kinerja

5. Inisialisasi dan kesalahan terminasi

Hasil dari pengujian penelitian ini, sistem yang dibangun sesuai dengan perancangan dan proses bisnis dalam pengelolaan pelanggan di BUMDesa Catu Krewo Sedana dan sistem yang dibangun dapat membantu proses pengelolaan pelanggan serta staff lapangan dapat mudah mencari lokasi pelanggan untuk memberikan pelayanan yang baik terhadap pelanggannya.

\section{SARAN}

Sistem yang dibangun masih terbatas pada sistem informasi berbasis web dan belum terdapat register untuk pelanggan. Saran dalam pengembangan sistem untuk dibangun dalam sistem berbasis mobile yang dapat diinstall di perangkat pelanggan untuk memudahkan pengelolaan data serta notifikasi oleh pelanggan serta sopir pengangkut sampah.

\section{UCAPAN TERIMA KASIH}

Ucapan terima kasih penulis sampaikan kepada semua pihak yang telah membantu penelitian ini, lembaga penelitian dan pengabdian di kampus STIKI Indonesia atas fasilitas serta dorongan untuk penyelesaian penelitian ini, teman kolega dan mahasiswa yang membantu sampai terpublikasikannya penelitian ini.

\section{DAFTAR PUSTAKA}

[1] C. Chalkias and K. Lasaridi, "A GIS based model for the optimisation of municipal solid waste collection : the case study of Nikea, Athens , Greece," vol. 5, no. 10, pp. 640-650, 2009.

[2] M. Sureshkumar, R. Sivakumar, and M. Nagarajan, "A Geo-Information System for Optimum Municipal Solid Waste Management ( A Case Study of Kanchipuram Municipality, Tamil Nadu , India )," vol. 9, no. 37, 2016.

[3] F. M. for E. C. and Development, "Promoting the use of ( GIS ) for Improvement of Solid Waste Management Services," Zamalek, 2014.

[4] D. S. Le Vie, "Understanding Data Flow Diagrams."

[5] C. Kiel, "David Embley, Bernhard Thalheim A Handbook," no. March, 2016.

[6] J. Speelpenning, J. Lounsberry, and A. Price-budgen, "Data Modeling and Relational Publishers," vol. 1, no. July, 2001.

[7] S. Nidhra and J. Dondeti, "BLACK BOX AND WHITE BOX TESTING TECHNIQUES -A LITERATURE REVIEW," Int. J. Embed. Syst. Appl., vol. 2, no. 2, 2012. 